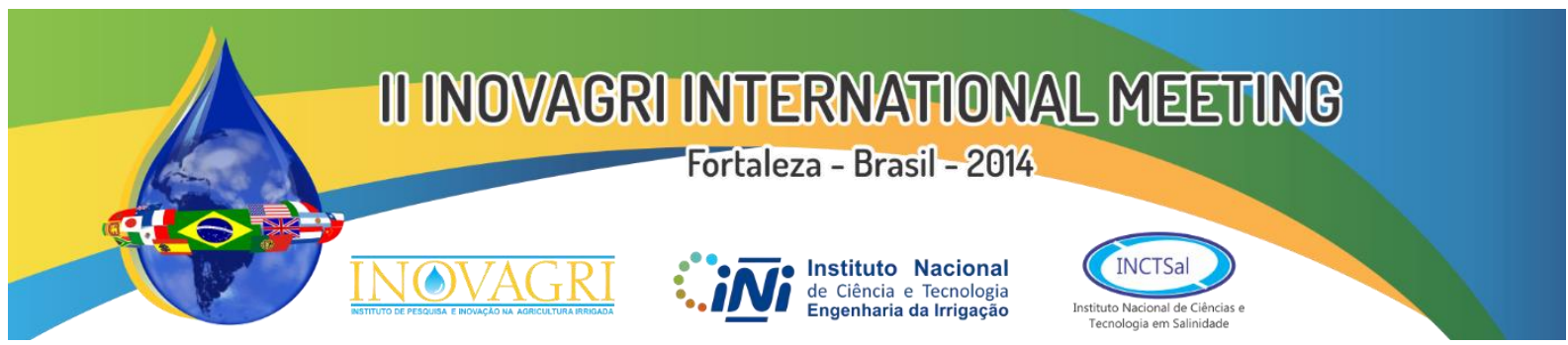

http://dx.doi.org/10.12702/ii.inovagri.2014-a100

\title{
SUGAR CANE ENERGY AND WATER BALANCES BY REMOTE SENSING IN THE SÃO PAULO STATE, BRAZIL
}

\author{
A. H. de C. Teixeira ${ }^{1}$, R. G. Andrade ${ }^{2}$, J. F. Leivas ${ }^{2}$, C. C. Ronquim, D. de C. Victoria ${ }^{2}$, F. B. T. \\ Hernandez ${ }^{3}$
}

\begin{abstract}
The north-eastern portion of São Paulo State is highlighted by large areas cultivated with sugar cane. Considering these land use changes, a MODIS product was coupled with agrometeorological data for quantification of the energy and water balance components, along the year of 2012. Two management types were considered, harvest with and without burning. For both management types, the fraction of net radiation $\left(\mathrm{R}_{\mathrm{n}}\right)$ used as latent heat flux $(\lambda \mathrm{E})$, ranged, from 0.27 to 0.87 , while that for the sensible heat flux $(\mathrm{H})$ was between 0.13 and 0.74 . With burnt harvest sugar cane, the crop used until $5 \%$ less and 6\% more of the available energy for, respectively, evapotranspiration (ET) and heating of air. For soil moisture conditions analyses, thermo-hydrological indices were applied, evidencing some situations where $120 \mathrm{~mm}$ of irrigation water should be beneficial for yield, during the period from July to October. The main results of this research are the quantification of the energy and water balance components on a large scale and the influence of the sugar cane harvest managements on these exchanges processes and the supplementary irrigation needs.
\end{abstract}

KEYWORDS: net radiation, latent heat flux, sensible heat flux.

\section{BALANÇOS DE ENERGIA E DE ÁGUA POR SENSORIAMENTO REMOTO NA CULTURA DA CANA-DE-AÇÚCAR NO ESTADO DE SAO PAULO, BRASIL}

RESUMO: A porção nordeste do Estado de São Paulo destaca-se pelas grandes áreas cultivadas com canade-açúcar. Considerando estas mudanças de uso da terra, um produto MODIS foi usado em conjunto com dados agrometeorológicas para a quantificação dos componentes dos balanços de energia e de água, ao longo do ano de 2012. Dois tipos de manejo foram considerados, colheita da cana com e sem queima. Para ambos os tipos de manejo, a parcela do saldo de radiação $\left(\mathrm{R}_{\mathrm{n}}\right)$ usada como fluxos de calor latente $(\lambda \mathrm{E})$, variou de 0,27 a 0,87 , enquanto que aquela para o fluxo de calor sensível (H) esteve entre 0,13 e 0,74 . Com queima na colheita a cultura usou até 5\% menos e 6\% mais da energia disponível para, respectivamente, os processos de evapotranspiração (ET) e para aquecimento do ar. Para análises das condições de umidade do solo, um índices termo hídricos foram aplicados, evidenciando algumas situações de benefícios de irrigações suplementares para a produção, no período de julho a outubro. Os principais resultados são a quantificação dos components dos balanços de energia e de água em larga escala e da influência dos manejos de colheita da cultura nas trocas energéticas e as necessidades da irrigação suplementar.

PALAVRAS-CHAVE: saldo de radiação, fluxo de calor latente, fluxo de calor sensível.

${ }^{1}$ Ph.D., Embrapa Satellite Monitoring, 13070-115, Campinas, SP. Phone $55 \quad 1932116200 . \quad$ e-mail: heriberto.teixeira@embrapa.br

${ }^{2}$ Doctor, Geosciences Department, Embrapa Satellite Monitoring, Campinas, SP.

${ }^{3}$ Professor, Hydrological and Irrigation Division, UNESP, Ilha Solteira, SP.

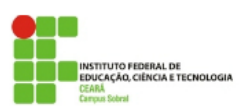




\section{INTRODUCTION}

In the north-eastern region of São Paulo State, rapid land use changes are occurring, during the last decades. This State is highlighted with more than 50\% of the Brazilian areas cultivated with sugar cane, which are approximately 8,500,000 ha. Highlights are for the growing region of Ribeirão Preto. In this region, the crop have optimum natural conditions for its development; a warm and wet period with high levels of solar radiation during the growth stage, followed by a dry and colder period during the phases of maturation and harvest (Ferraz et al., 2007).

Nowadays, the beneficial ecological aspects of ethanol from sugar cane has increased its cultivation, which in turn can raise the competition for land and for water. The effects of ethanol production from agricultural crops in areas previously habited by natural vegetation can be more prejudicial than fossil fuel in relation to greenhouse gas emissions (Fargione et al., 2008; Scharlemann et al., 2008). However, the expansion of areas with sugar cane in the north-eastern side of São Paulo has caused replacement of pasture, citrus, grains and coffee, which had already replaced the natural vegetation (Rudorf, et al., 2010). This expansion can affect the energy and water balances by increasing the greenhouse gases emissions (Cerri et al., 2011).

Anderson-Teixeira et al. (2012) reported that bioenergy crops such sugar cane can alter the local climate by increasing the latent heat fluxes; consequently reducing air temperature close to the canopies. Loari et al. (2011), analysing remote sensing data from satellites, concluded that the deforestation of the Brazilian scrubland for cattle and soybean crops raised the air temperature; however, when these last crops were replaced by sugar cane the thermal conditions reduced again.

The difficulties to measure the energy fluxes from mixed agro-ecosystems by field experiments make remote sensing by satellite images a valuable application and its use for this purpose has already been done in different climate regions (Anderson et al., 2012; Pôças et al., 2013; Teixeira et al., 2013). Considering the simplicity of application, the SAFER (Surface Algorithm For Evapotranspiration Retrieving) algorithm for the energy balance quantification was developed. This model together with net radiation $\left(\mathrm{R}_{\mathrm{n}}\right)$ estimations allow the determination of the spatial daily values of latent $(\lambda \mathrm{E})$ and sensible $(\mathrm{H})$ heat fluxes (Teixeira et al, 2013).

The objective of the current research was to apply SAFER together with MODIS images and a net of agrometeorological stations for quantification of the large-scale energy and water balances components in the sugar cane cultivated with burnt and not burnt harvest inside the growing regions in the north-eastern side of São Paulo State, Brazil. The results can subsidize criteria for policy decisions when aiming a rational water resources management in conditions of fast replacement of natural vegetation species by this crop. The success of the modelling here may give more confidence for the test and validations in other sugar cane environments, which probably will need only calibrations of the original equations.

\section{MATERIAL AND METHODS}

Figure 1 shows the location of the net of agrometeorological stations and the burnt and not burnt harvest sugar canes in the north-eastern side of São Paulo (SP) State, Southeast of Brazil. 

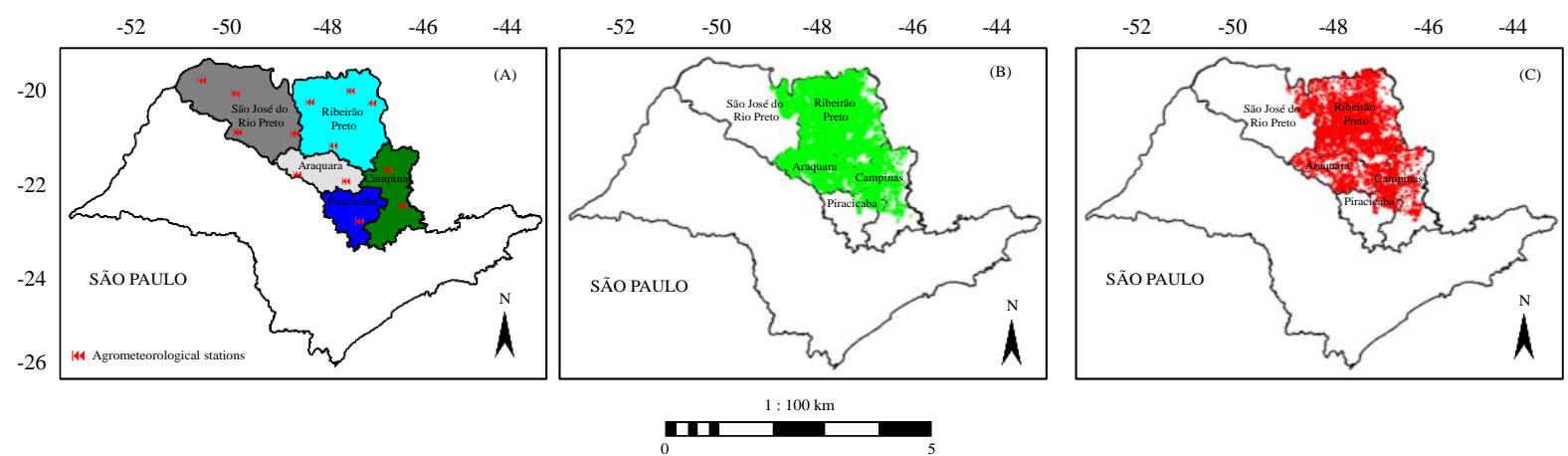

Figure 1 - Location of the sugar cane growing regions and agrometeorological stations used for the interpolation processes in São Paulo (SP) State, Southeast of Brazil (A). Crops with no harvest burn (green) management (B); and crops with harvest burn (red) management (C).

MODIS is an on board sensor of Terra platform, with 36 spectral bands, acquired at 3 spatial resolutions $(250,500$ and $1000 \mathrm{~m})$. For the surface albedo $\left(\alpha_{0}\right)$ the reflectance product MOD13Q1 for 16 days during 2012 was used and the bands 1 and 2, with a spatial resolution of 250m were extracted:

$$
\alpha_{0}=a+b \alpha_{1}+c \alpha_{2}
$$

where $\alpha_{1}$ and $\alpha_{2}$ are the reflectances for the bands 1 and 2 from MODIS satellite measurements, and a, $\mathrm{b}$, and $\mathrm{c}$ are regression coefficients, considered as, respectively, 0.08, 0.41 and 0.14 (Teixeira et al., 2013).

For the energy and water balances components estimations, the Normalized Difference Vegetation Index (NDVI) was an input, because it is a measure of the amount of vegetation at the surface:

$$
\mathrm{NDVI}=\frac{\alpha_{\mathrm{p}_{(2)}}-\alpha_{\mathrm{p}_{(1)}}}{\alpha_{\mathrm{p}_{(2)}}+\alpha_{\mathrm{p}_{(1)}}}
$$

where $\alpha_{\mathrm{p}(2)}$ and $\alpha_{\mathrm{p}(1)}$ represent the planetary albedo over ranges of wavelengths in the near infrared (MODIS band 2) and red (MODIS band 1) regions of the solar spectrum, respectively (Teixeira et al., 2013).

Aiming to improve the spatial resolution in the current research, instead of using the thermal band $(120 \mathrm{~m}), \mathrm{T}_{0}$ in the current study was estimated with only the red (band 2) and infrared (band 1) spectral regions, together with weather data. I was acquired as a residual in the radiation balance equation:

$$
\mathrm{R}_{\mathrm{n}}=\mathrm{RS} \downarrow-\alpha_{0} \mathrm{RS} \downarrow-\varepsilon_{0} \sigma \mathrm{T}_{0}^{4}+\varepsilon_{\mathrm{a}} \sigma \mathrm{T}_{\mathrm{a}}^{4}
$$

where $R S \downarrow$ and $T_{a}$ are respectively the daily values of the incident solar radiation and mean air temperature from the agrometeorological stations; $R_{n}$ is the daily net radiation; $\varepsilon_{0}$ and $\varepsilon_{\mathrm{a}}$ are respectively the surface and atmospheric emissivities; and $\sigma$ is the Stefan-Boltzmann constant (5.67 $\left.10^{-8} \mathrm{~W} \mathrm{~m}^{-2} \mathrm{~K}^{-4}\right)$.

$\varepsilon_{0}$ and $\varepsilon_{\mathrm{a}}$ were calculated as following:

$$
\begin{aligned}
& \varepsilon_{0}=\mathrm{a}_{0} \ln \mathrm{NDVI}+\mathrm{b}_{0} \\
& \varepsilon_{\mathrm{a}}=\mathrm{a}_{\mathrm{a}}\left(-\ln \tau_{\mathrm{s}}\right)^{\mathrm{b}_{\mathrm{a}}}
\end{aligned}
$$


where $\tau_{\mathrm{s}}$ is the short wave transmissivity calculated as the ratio of RS $\downarrow$ to the incident solar radiation at the top of the atmospheric; and $\mathrm{a}_{0}, \mathrm{~b}_{0}, \mathrm{a}_{\mathrm{a}}$ and $\mathrm{b}_{\mathrm{a}}$ are regression coefficients taking as $0.06,1.00,0.94$ and 0.10 according to Teixeira et al. (2013).

The Slob equation for acquiring the daily values of $R_{n}$, is described as:

$$
\mathrm{R}_{\mathrm{n}}=\left(1-\alpha_{0}\right) \mathrm{RS} \downarrow-\mathrm{a}_{1} \tau_{\mathrm{w}}
$$

where the regression coefficient $\mathrm{a}_{1}$ was obtained throughout its relation with $\mathrm{T}_{\mathrm{a}}$ (Teixeira et al., 2013).

Having calculated the input parameters for the SAFER algorithm, the daily ET was estimated with $\mathrm{ET}_{0}$ daily data for this time-scale:

$$
\frac{\mathrm{ET}}{\mathrm{ET}_{0}}=\exp \left[\mathrm{d}+\mathrm{e}\left(\frac{\mathrm{T}_{0}}{\alpha_{0} \mathrm{NDVI}}\right)\right]
$$

where $\mathrm{d}$ and $\mathrm{e}$ are regressions coefficients, which for the north-western side of São Paulo were considered 1.0 and -0.008 , respectively (Teixeira et al., 2013).

Transforming ET into energy units, the latent heat flux $(\lambda \mathrm{E}) 24$ hours values were obtained, and then the sensible heat flux $(\mathrm{H})$ estimated as the residual in the energy balance equation, neglecting the soil heat flux (G) for this time scale (Teixeira et al., 2013):

$$
\mathrm{H}=\mathrm{R}_{\mathrm{n}}-\lambda \mathrm{E}
$$

As soil moisture indices, the evaporative fraction (EF) and a water indicator (WI) were used:

$$
\begin{aligned}
& \mathrm{Ef}=\frac{\lambda E}{\mathrm{R}_{\mathrm{n}}} \\
& \mathrm{WI}=\frac{\mathrm{P}}{\mathrm{ET}}
\end{aligned}
$$

where $\mathrm{P}$ is precipitation from the agrometeorological stations at time-scale of 16 days.

The indicator represented by Eq. 10 enables the characterization of the water component of the climate, taking into account the input and output of water from and to the sugar canes, indicating the potential moisture availability in their root zones. Low WI values mean natural water deficiencies and the degree of irrigation needs.

\section{RESULTS AND DISCUSSION}

\section{Weather conditions}

Energy balance partition depends on the atmospheric demand and soil moisture, which in turn are conditioned by solar radiation (RS $\downarrow$ ) and precipitation (P) levels. Figure 2 shows the monthly variation of RS $\downarrow$, ET0 and P through the year of 2012 as average of sugar cane pixels in the study area. 


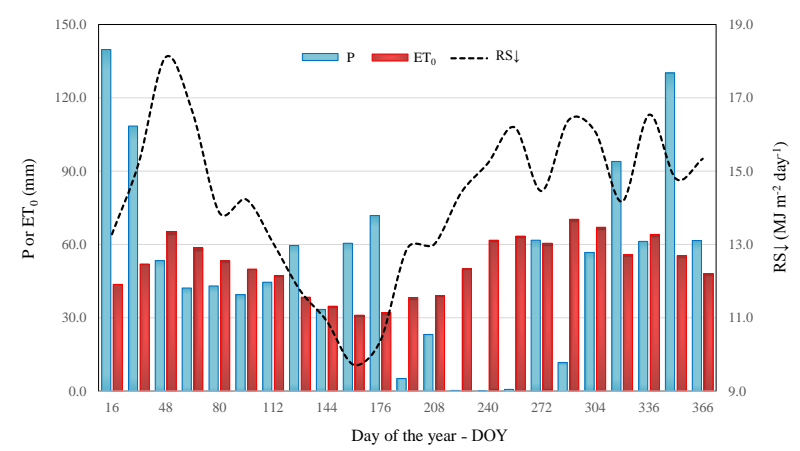

Figure 2 - Seasonal total values of reference evapotranspiration $\left(\mathrm{ET}_{0}\right)$ and precipitation $(\mathrm{P})$, together with the average daily values of incident solar radiation (RS $\downarrow$ ) in the sugar cane area during the year of 2012, in the north-eastern side of São Paulo State.

$\mathrm{RS} \downarrow$ represents the main source for the energy and water balances. Its values were lower between the day of the year (DOY) from 144 to 172 (May - June), around $10.3 \mathrm{MJ} \mathrm{m}^{-2}$ day $^{-1}$, period close to the winter solstice in the South hemisphere. Two picks occurred DOY between DOY 32 and 96 (February - April) and from DOY 256 to 336 (September - December), averaging $15.6 \mathrm{MJ} \mathrm{m}^{-2} \mathrm{day}^{-}$ ${ }^{1}$, when the sun is near the zenith position at the sugar cane growing regions. Higher RS $\downarrow$ during these last period contributed to larges atmosphere demands.

$\mathrm{ET}_{0}$ and $\mathrm{P}$ in Figure 2 represent the totals for each 16 days corresponding to the time scale from the MODIS product used. Although the largest $\mathrm{ET}_{0}$ values occurring at the end of the year, reaching to $4.4 \mathrm{~mm} \mathrm{day}^{-1}$ from DOY 272 to 288 (September - October), the variations along the year is not so big when comparing with the corresponding ones for $\mathrm{P}$. The only periods with $\mathrm{ET}_{0}$ lower than $2.0 \mathrm{~mm}$ day $^{-1}$ were from DOY 144 to 160 (May - June). Considering P as the natural input in the water balance, much strong variation along the year were verified, with the highest values, $140 \mathrm{~mm}$ from DOY 001 to 016 (January), while between for DOY between 208 and 256 (July - September) P was less than $1 \mathrm{~mm}$ for this time-scale.

Taking the difference between $\mathrm{P}$ and $\mathrm{ET}_{0}$ as a crude measure of water availability and the period of 16 days in the sugar cane growing regions, the climatic water balance was quantified during 2012. The large water excesses (P > ET0) happened in January during the DOY from 001 to 016 (96 mm) and in December from DOY between 336 and $352(75 \mathrm{~mm})$, while the highest climatic water deficit (P - ET0 < 0) reached until $63 \mathrm{~mm}$ month $^{-1}$ from August to September (DOY 240 to 256). As the different stages of sugar cane crop happen throughout the year, the need of supplementary irrigation (SI) is evident, which should be based on crop water requirements. Modelling the energy and water balance during these different stages of the crop is the first step and the challenge for the researchers when aiming a sustainable activity. The second one is related to the extension services for disseminating the measurement tools with sufficient accuracy.

\section{Remote sensing parameters}

Figure 3 presents the spatial distribution of the model input parameters for the sugar cane growing regions through the year of 2012 in the north-eastern side of São Paulo (SP) State. 


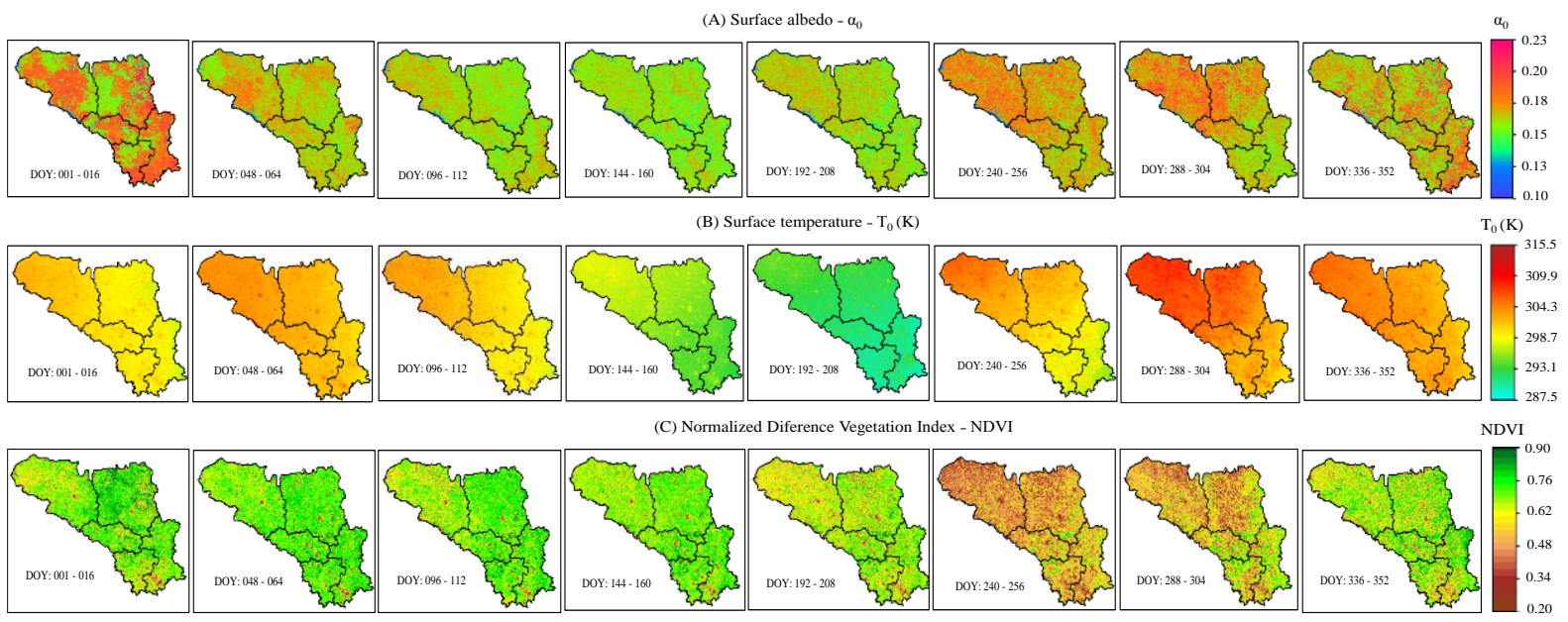

Figure 3 - Spatial distribution of the model input remote sensing parameters for the sugar cane growing regions of São Paulo (SP) State, South-east of Brazil, for specific days of the year (DOY) in 2012. (A) surface albedo - $\alpha_{0}$; (B) surface temperature - $\mathrm{T}_{0}$; and (C) Normalized Difference Vegetation Index - NDVI.

Most $\alpha_{0}$ pixel values stayed in the range from 0.11 to 0.23 with the highest values observed from DOY 001 to 064 (January - March) and between DOY 240 and 352 (August - December), while the lowest ones occurring from DOY 096 to 208 (April - July). This variation is a result of the apparent movement of Sun along the year, proportioning different RS $\downarrow$ levels (Figure 3A). The sugar cane areas were extracted by using the masks for harvest not burnt (NB) and burnt (B) harvest. When comparing these areas with those for the growing regions, it was respectively observed average $\alpha_{0}$ values till 12\% higher in October (DOY 288 - 304) and 6\% lower from August to September (DOY 240 - 256). The differences could be related different soil moisture conditions ( $\mathrm{Li}$ et al., 2006; Teixeira et al., 2008, Teixeira et al., 2013)

$\mathrm{T}_{0}$ affects the available energy, interfering in the long wave radiation balance because it drives the emitted long wave radiation via Stefan-Boltzman equation (Teixeira et al., 2008). The most frequent $\mathrm{T}_{0}$ values for the sugar cane growing areas were between 301.0 and $313.5 \mathrm{~K}$ (Figure 3B). The lowest ones happened between DOY 144 and 208 (May - July), while the highest thermal conditions were between DOY 288 and 352 (October - December). In general, the periods with the highest $\mathrm{T}_{0}$ coincided with those with the largest RS $\downarrow$ (see Figure 2). For the NB and B sugar cane areas, reductions of 0.6 and $0.7 \mathrm{~K}$ in January (DOY 001 to 016 ) were respectively observed, when compared with values from the growing regions. Although with small magnitude, these thermal differences are in agreement with Anderson-Teixeira et al. (2012).

The variation of NDVI values in the sugar cane growing regions along the year is evident (Figure 3C). The pixel values stayed in the range from 0.20 to 0.88 with the highest ones observed from DOY 001 to 112 (January - April), while the lowest ones happened between DOY 240 and 304 (August - October) when total $\mathrm{P}$ values were lower than $1 \mathrm{~mm}$. There is a time lag for the lower values in relation to $\alpha_{0}$ and $\mathrm{T}_{0}$. The smallest pixel amplitude is also verified during this period, when after the rainy period, the soil in the root zones is uniformly dry in the mixed agro-ecosystems, what can be seen by the brown colour in the Figure 3C. Extracting NB and B sugar cane areas from the growing regions there were NDVI increases and reductions along the year, however considering the annual scale, there were no differences for NB management, while for B one the value was $2 \%$ higher.

The seasonal behaviour of the averaged pixel values of the model remote sensing input parameters were also analysed only for NB and B areas through the year of 2012 (Figure 4) 

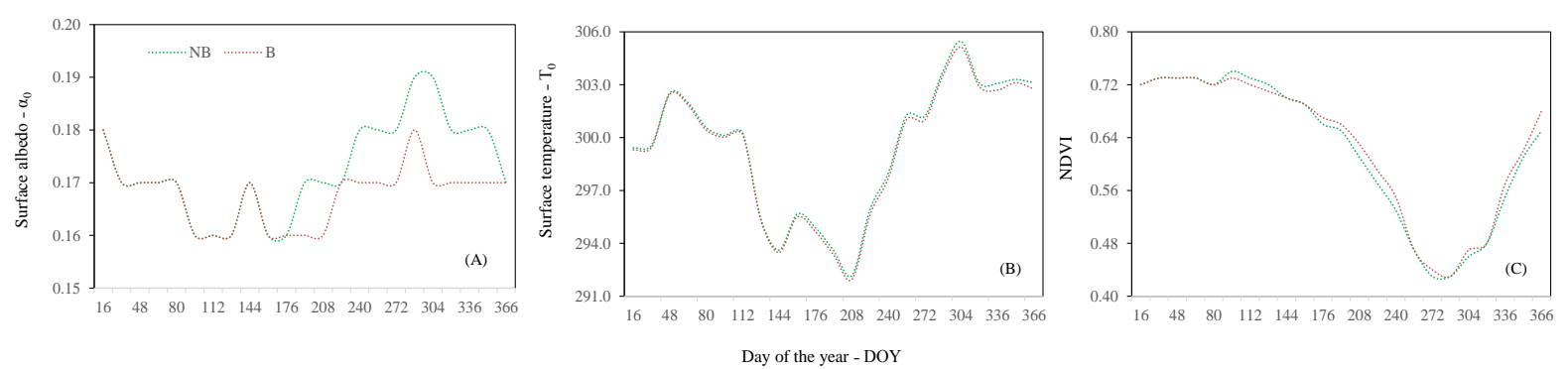

Figure 4 - Mean pixel values (16 days) of the model input remote sensing parameters in the not burnt (NB) and burnt (B) harvest sugar cane areas, in the growing regions of the north-eastern side of São Paulo (SP) State in 2012. (A) surface albedo - $\alpha_{0}$; (B) surface temperature - $\mathrm{T}_{0}$; and (C) the Normalized Difference Vegetation Index - NDVI.

The average $\alpha_{0}$ pixel values ranged from 0.16 to 0.19 , for both, NB and B managements. The largest differences between them were in October from DOY 288 to 304, when reached to 12\%, being the high values for the NB management (Figure 4A). This means that the NB harvest management will reflect more solar radiation, contributing for lowering the available energy to the crop. Taking the annual average, sugar cane areas with NB management presented values 3\% higher than those under B management.

The majority mean $\mathrm{T}_{0}$ pixel values were in the range from $292.0 \mathrm{~K}$ to $303.3 \mathrm{~K}$. A difference until $0.4 \mathrm{~K}$ between the two management types was observed from DOY 320 to 336 (November December), with the highest values for NB management (Figure 4B). Although small, these thermal differences can be significant considering the emitted long-wave radiation in large crop areas. The high $\mathrm{T}_{0}$ for NB management will also contribute to reduce the available energy to the crop.

Considering the seasonal average sugar cane NDVI pixel values, they were between 0.43 and 0.74 (Figure 4C). The lowest ones happened during the periods with low rain amounts, which induced a natural water deficit (see Figure 2). In relation to the management types, during the first semester, NB presented a little higher values, while for the second semester this situation inverted. However, considering the whole period, B management had sugar cane NDVI mean values $1 \%$ higher. As the sugar canes are in the same thermo-hydrological conditions, probably, the management types influenced the proportion of red and infrared reflectivity.

\section{Energy balance components}

Figure 5 shows the trend of the energy balance components for selected periods along the year of 2012 for the sugar cane growing regions in the north-eastern side of São Paulo State (SP).

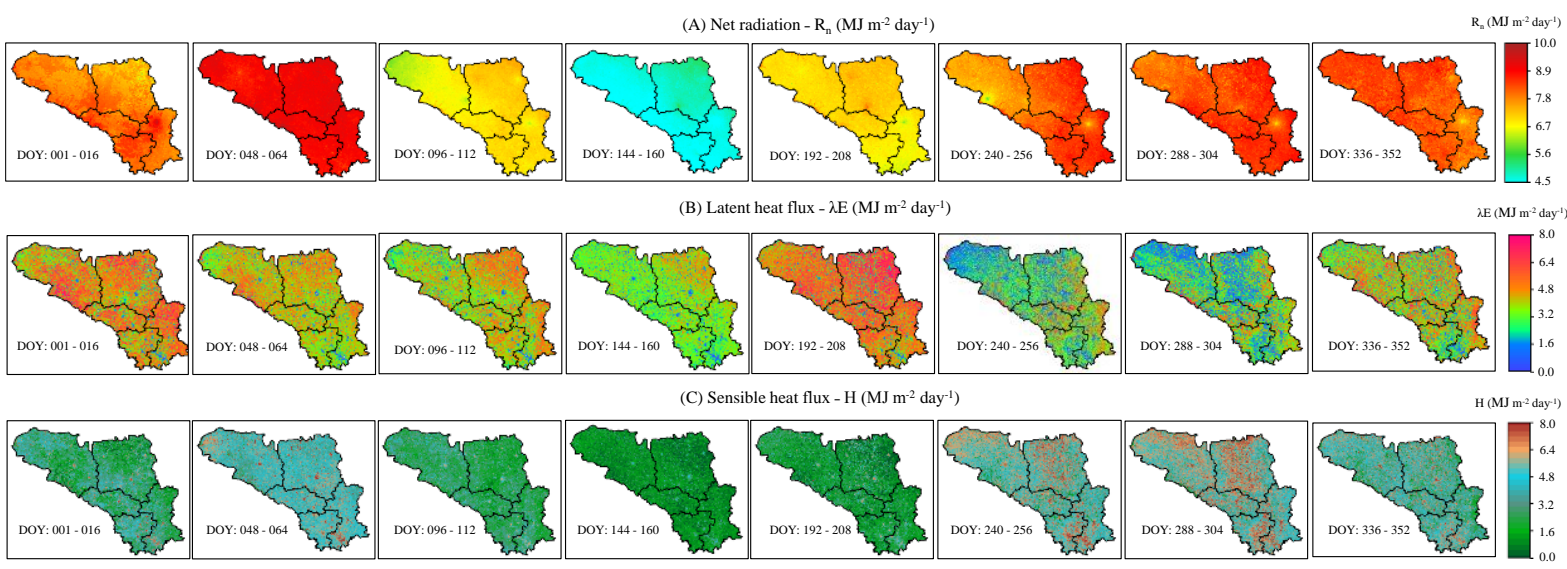

Figure 5 - Spatial distribution of the energy balance components in the sugar cane growing regions of São Paulo (SP) State, for specific days of the year (DOY) in 2012. (A) net radiation - $R_{n}$; (B) latent heat flux $-\lambda E$; and $(C)$ sensible heat flux $-\mathrm{H}$. 
There are clear distinctions among the $R_{n}$ values according to the time of the year (Figure $5 A$ ), being evidenced a strong dependence of them with RS $\downarrow$ levels (see Figure 2). Most $R_{n}$ pixel values stayed in the range from 4.2 to $9.7 \mathrm{MJ} \mathrm{m}^{-2}$ day $^{-1}$, with the highest ones observed from DOY 048 to 064 (February - March) and between DOY 144 and 160 (May - June), while the lowest values happened from DOY 096 to 208 (April - July) as consequences of the variation of RS $\downarrow$ levels (see Figure 2). When comparing the sugar cane areas with those for the entire growing region, no significant differences were observed.

Although depending of RS $\downarrow$ levels, the available energy partition is also related to soil moisture, which in turn, under natural ecosystems, depends only on the rainfall amounts. Clearly one can distinguish different moisture conditions through the year by the $\lambda \mathrm{E}$ spatial variation (Figure 5B). Considering the whole year, the pixel values were concentrated between 0.2 and $8.1 \mathrm{MJ} \mathrm{m}^{-2} \mathrm{day}^{-1}$. The lowest ones happened from DOY 240 to 304 (August - October), while the highest evaporative conditions were between DOY 192 and 208 in July. This last period coincided with the end of the rainy period together with increasing RS $\downarrow$ (see Figure 2). Extracting NB and B sugar cane areas there were increase until 15\% and 12\% in April during DOY from 096 to 112 for NB and B management, respectively, when comparing with the growing regions. These differences are in agreement with Anderson-Teixeira et al. (2012).

Neglecting the daily values of soil heat flux $(\mathrm{G}), \mathrm{H}$ was derived as a residual in the energy balance equation (Figure 5C). It is a plausible assumption, as it has been demonstrated that 24 hour values for this last energy balance component is close to zero for irrigated crops and natural vegetation in Brazil (Teixeira et al., 2008). $\mathrm{H}$ is also related to soil moisture conditions, but in this case the lower values occurred with high amounts of rainfall, being even zero in some occasions during the period between DOY 144 and 208 (May - July), at the end of the rainy period. Through the year of 2012, the $\mathrm{H}$ pixel values were concentrated between 0.0 and $5.4 \mathrm{MJ} \mathrm{m}^{-2}$ day $^{-1}$, with the highest ones happening after DOY 208 (July) and before DOY 304 (October), the driest period of the year. For the NB and B sugar cane areas, increases in October as much as 13 and 15\% from DOY 288 to 304 were respectively observed, when compared with the sugar cane growing regions.

The seasonal behaviour of the averaged pixel values of energy balance components were analysed for the sugar cane areas through the year of 2012 (Figure 6)
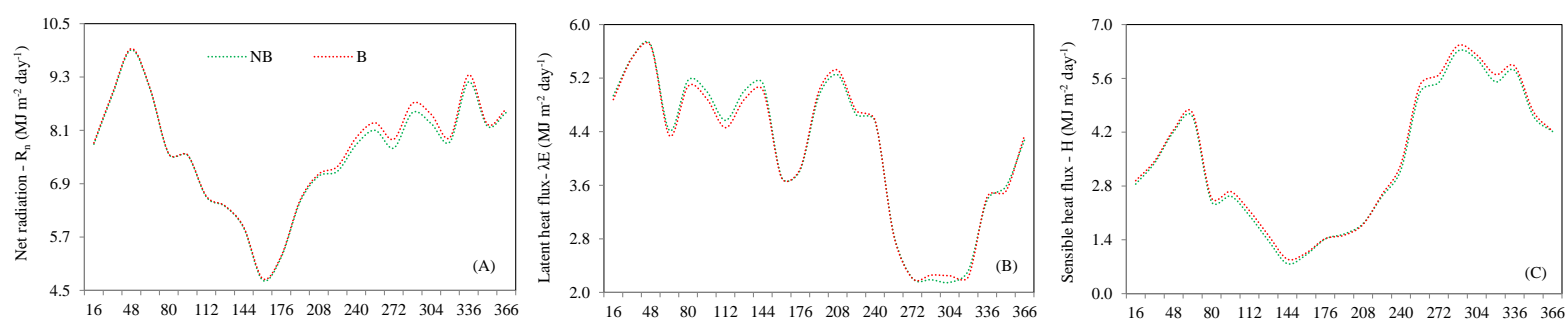

Day of the year - DOY

Figure 6 - Mean pixel values (16 days) of the energy balance components in the not burnt (NB) and burnt (B) harvest sugar cane areas, in the growing regions of the north-eastern São Paulo (SP) State in 2012. (A) net radiation - $\mathrm{R}_{\mathrm{n}}$; (B) latent heat flux - LE; and the sensible heat flux - H.

The average $R_{n}$ pixel values ranged from 4.7 to $9.9 \mathrm{MJ} \mathrm{m}^{-2} \mathrm{day}^{-1}$, including both, the not burnt (NB) and burnt (B) harvest sugar canes. The largest differences, between the management types, were from DOY 240 to 304 (August - October), when reached to 3\% with the highest values for the B management (Figure 6A). This is a result of the high both, reflected (short wave) and emitted (long wave) radiation, respectively, for the NB. Considering the whole year, B management contributed to $1 \%$ more available energy than NB management.

The mean $\lambda \mathrm{E}$ pixel values were in the range from 2.2 to $5.7 \mathrm{MJ} \mathrm{m}^{-2}$ day $^{-1}$. The highest ones were for the NB management (Figure 6B). A difference until 13\% between B and NB was observed from DOY 80 to 128 (March - May). Considering the fraction of $R_{n}$ used as $\lambda E$ these fractions ranged from 0.27 to 0.87 . The highest values occurred in May from DOY 128 to 144 , above $80 \%$ for both 
managements, while the lowest ones, bellow 30\%, happened from September to October (DOY 256 288).

Considering the sugar cane average $\mathrm{H}$ pixel values, they presented an opposite behaviour of that for $\lambda \mathrm{E}$, staying between 0.8 and $6.5 \mathrm{MJ} \mathrm{m}^{-2}$ day $^{-1}$ (Figure 6C). The lowest ones happened at the end of the rainy period, from DOY 128 to 160 (May - June) (see Figure 2), when the evaporative fraction Ef (Eq. 9) indicated the highest soil moisture conditions. With exception for the period from DOY 176 to 204 (June - July), NB presented a little lower H values, while for the other periods B management presented high values until more $15 \%$ more. Considering the fraction of $\mathrm{R}_{\mathrm{n}}$ used as $\mathrm{H}$ they ranged from 0.13 to 0.74 . The highest ones occurred from DOY 272 to 304 (September - October), above $70 \%$ for both managements, while the lowest, bellow 23\%, happened from DOY 128 to 160 (May June).

\section{Water balance components}

After transforming $\lambda E$ into evapotranspiration (ET) and having the available energy $\left(\mathrm{R}_{\mathrm{n}}\right)$ and precipitation $(\mathrm{P})$ it was possible to analyse the soil moisture conditions and the water balance components at a time-scale of 16 days, considering the average both NB and B managements (Figure 7).
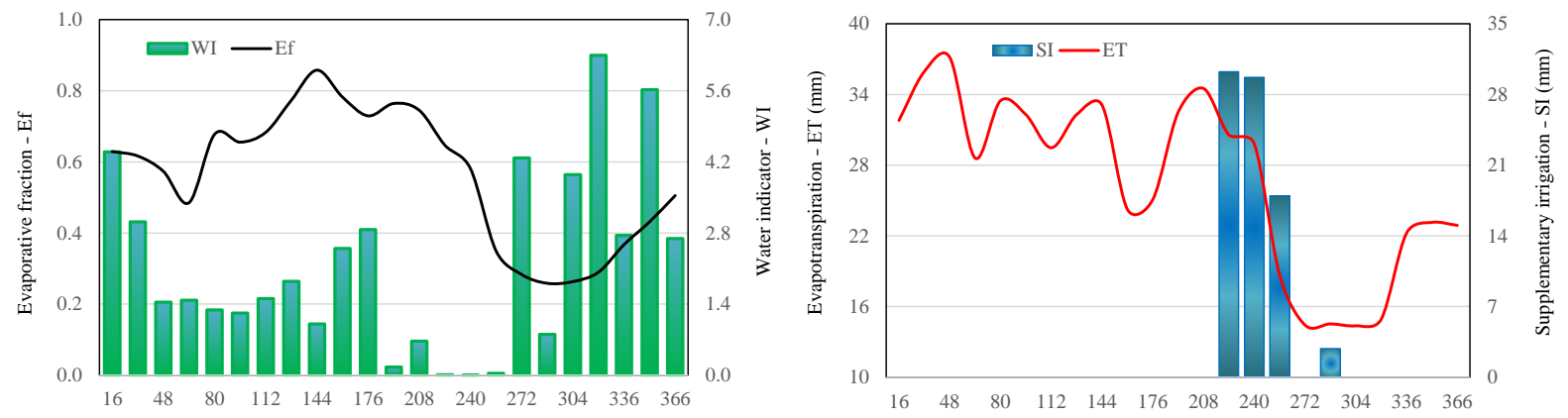

Day of the year - DOY

Figure 7 - Soil moisture indicators and irrigation needs for the sugar cane areas in the north-eastern side of São Paulo (SP) State in 2012. (A) Evaporative fraction - Ef and water indicator - WI; (B) evapotranspiration - ET and supplementary irrigation - SI.

It is well-known that $\mathrm{Ef}$ is a good indicator for soil moisture conditions in different types of vegetation. Teixeira et al. (2008) have correlated this energy balance parameter with soil moisture through field experiments with irrigated fruit crops. In the current research, for estimation of the supplementary irrigation (SI), it was used together with the water indictor (WI) which takes into account the natural water input $(\mathrm{P})$ and output $(\mathrm{ET})$ in the sugar cane areas.

Figure 7A shows the seasonal behaviour of Ef and WI for each 16 days, while Figure 7B presents the ET seasonal values together with SI for the same time-scale. On one hand, it can be seen a time lag between WI and Ef. On the other hand, it is observed that ET is at higher rates when Ef is above 0.70. The WI values were below 1.0 from DOY 160 to 256 (June - September) and again between DOY 272 (September) and 288 (October) but Ef values started to decline bellow 0.70 only at DOY 208 (July), continuing until DOY 304 (October), when started to increase again. Then taking into account WI values bellow 1.0 and Ef lower than 0.7 a criterion for SI was established to ensure the ET at good levels if there is water availability for irrigation. Then, these water applications should be done between DOY 208 and 288 (July - October) totalling an amount around $120 \mathrm{~mm}$ to avoid crop water deficits for the sugar canes during this period. 


\section{CONCLUSIONS}

The coupled use of remote sensing and agrometeorological stations allowed the quantification and analyses of the energy balance on a large-scale along the year of 2012 in the sugar cane growing regions located at the north-eastern side of São Paulo State, Southeast Brazil. It was demonstrated that the daily fluxes of latent and sensible heat fluxes can be estimated from instantaneous measurements of the red and infrared radiations from MODIS sensor, throughout the modelling of the ratio of the actual to reference evapotranspiration at the satellite overpass time. Two management types were analysed, not burnt and burnt harvest sugar cane. Net radiation is most strongly influenced by the solar radiation conditions than the characteristics of different kind of sugar cane management. However, not burnt and burnt harvest management types influenced the energy partition, mainly by differences in surface albedo and surface temperature, being theses remote sensing parameters higher under the management with no burn at harvest. These large-scale analyses can contribute for the monitoring of the land use and climate changes effects in large sugar cane areas.

\section{Acknowledgements}

To CNPq, for the financial support to the projects on water productivity; INPE (Drs. Daniel Alves de Aguiar e Bernardo Friedrich Theodor Rudorff), for providing the sugar cane masks; and INMET, for the availability of the weather data.

\section{REFERENCES}

ANDERSON, M.C., KUSTAS, W.P., ALFIERI, J.G., GAO, F.N., HAIN, C., PRUEGER, J.H., EVETT, S.R., COLAIZZI, P.D., HOWELL, T.A., CHAVEZ, J. Mapping daily evapotranspiration at Landsat spatial scales during BEAREX'08 field campaign. Advances in Water Resources, v.50, p. 162-177, 2012. http://dx.doi.org/10.1016/j.advwatres.2012.06.005

ANDERSON-TEIXEIRA, K. J.; SNYDER, P. K.; TWINE, T. E.; CUADRA, S. V.; COSTA, M. H.; DE LUCIA, E. H. Climate-regulation services of natural and agricultural ecoregions of the Americas. Nature Climate Change, v. 2, p. 177-181, 2012. http://dx.doi.org/10.1038/nclimate1346

CERRI, C.C.; GALDOS, M.V.; MAIA, S.M.F.; BERNOUX, M.; FEIGL, B.J.; POWLSON, D.; CERRI, C.E.P. Effect of sugarcane harvesting systems on soil carbon stocks in Brazil: an examination of existing data. European Journal of Soil Science, v. 62, p. 23-28, 2011. http://dx.doi.org/10.1111/j.1365-2389.2010.01315.x

FARGIONE, J.; HILL, J.; TILMAN, D.; POLASKY, S.; HAWTHORNE, P. Land clearing and the biofuel carbon debt. Science, v. 319, n. 5867, p. 1235-1238, 2008. http://dx.doi.org/10.1126/science.1152747

FERRAZ, F.M.; BRUNINI, O.; CARVALHO, J.P. de; BRUNINI, A.P.C. Potencialidade da cana-deaçúcar. São Paulo. Agrianual 2007 FNP, p. 23-28, 2007.

LOARIE, S.R.; LOBELL, D.B.; ASNER, G.P.; MU, Q. ; FIELD, C.B. Direct impacts on local climate of sugar-cane expansion in Brazil. Nature Climate Change, v. 1, p. 105-109, 2011. http://dx.doi.org/10.1038/nclimate1067

Li, S.-G., EUGSTER, W., ASANUMA, J, KOTANI, A., DAVAA, G., OYUNBAATAR, D., SUGITA, M. Energy partitioning and its biophysical controls above a grazing steppe in central Mongólia. Agricultural and Forest Meteorology, v. 137, p. 89-106, 2006. http://dx.doi.org/10.1016/j.agrformet.2006.03.010

MIRALLES, D.G., HOLMES, T.R.H., De JEU, R.A.M., GASH, J.H., MEESTERS, A.G.C.A., DOLMAN, A.J. Global land-surface evaporation estimated from satellite-based observations. Hydrology and Earth System Sciences, v.15, p. 453-469, 2011. http://dx.doi.org/10.5194/hess-15453-2011

PÔÇAS, I., CUNHA, M., PEREIRA, L.S., ALLEN, R.G. Using remote sensing energy balance and evapotranspiration to characterize montane landscape vegetation with focus on grass and pasture lands. International Journal of Applied Earth Observation and Geoinformation, v. 21, p. 159-172, 2013. http://dx.doi.org/10.1016/j.jag.2012.08.017 
RUDORFF, B.F.T.; AGUIAR, D.A.; SILVA, W.F.; SUGAWARA, L.M.; ADAMI, M.; MOREIRA, M.A. Studies on the rapid expansion of sugarcane for ethanol production in São Paulo State (Brazil) using Landsat Data. Remote Sensing, v. 2, p. 1057-1076, 2010. http://dx.doi.org/10.3390/rs2041057

SCHARLEMANN, J. P.; LAURANCE, W. F. How Green Are Biofuels? Science, v. 319, p. 43-44, 2008. http://dx.doi.org/10.1126/science.1153103

TEIXEIRA, A.H. de C., Bastiaanssen, W.G.M., Ahmad, M.D., Bos, M.G. Analysis of energy fluxes and vegetation-atmosphere parameters in irrigated and natural ecosystems of semi-arid Brazil. Journal of Hydrology, v. 362, p. 110-127, 2008. http://dx.doi.org/10.1016/j.jhydrol.2008.08.011

TEIXEIRA, A. H. de C.; HERNANDEZ, F. B. T.; LOPES, H. L.; SCHERER-WARREN, M.; BASSOI, L.H. A Comparative Study of Techniques for Modeling the Spatiotemporal Distribution of Heat and Moisture Fluxes in Different Agroecosystems in Brazil. In: George G. Petropoulos (Org.). Remote Sensing of Energy Fluxes and Soil Moisture Content. 1ed. Boca Raton, Florida: CRC Group, Taylor and Francis, 2013, p. 169-191. 